Article

\title{
Analysis of Air-Side Economizers in Terms of Cooling-Energy Performance in a Data Center Considering Exhaust Air Recirculation
}

\author{
Seonghyun Park ${ }^{1}$ and Janghoo Seo ${ }^{2, *}$ \\ 1 Department of Architecture, Graduated School, Kookmin University, 77 Jeongneung-ro, Seongbuk-gu, \\ Seoul 02707, Korea; marine86@kookmin.ac.kr \\ 2 School of Architecture, Kookmin University, 77 Jeongneung-ro, Seongbuk-gu, Seoul 02707, Korea \\ * Correspondence: seojh@kookmin.ac.kr; Tel.: +82-2-910-4593
}

Received: 24 January 2018; Accepted: 13 February 2018; Published: 17 February 2018

\begin{abstract}
Demand is soaring for data centers with advanced data-processing capabilities. In data centers with high-temperature information technology (IT) equipment, enormous cooling systems are operated year-round. To date, studies have aimed to improve the cooling efficiency of server-room units, but cooling-energy-consumption analysis considering the recirculation of exhaust air (EA) has not been researched to a sufficient degree. This study analyzed the cooling-energy saving effects considering the EA-recirculation and supply-air (SA)-temperature conditions when direct and indirect air-side economizers were applied to a data center in Korea. Thirteen case studies were conducted. The results showed that when the EA-recirculation ratio in the direct air-side economizer was $15 \%$, its annual cooling-energy consumption increased by approximately $6.1 \%$ compared to the case with no recirculation. The indirect air-side economizer also exhibited an approximately $9 \%$ increase in cooling-energy consumption. On the other hand, when the SA temperature changed to $22{ }^{\circ} \mathrm{C}$, the annual cooling-energy consumption of the direct and indirect air-side economizers decreased by approximately $67 \%$ and $55 \%$, respectively, compared to a central chilled-water system. This indicates the importance of developing measures to prevent EA recirculation and of securing a wind path for the improvement of air-conditioning efficiency in data centers at the design stage.
\end{abstract}

Keywords: data center; air-side economizer; energy simulation; cooling system; recirculation

\section{Introduction}

Demand is soaring for data centers with advanced data-processing capabilities, owing to the rapid advancement of the information technology (IT) industry [1,2]. The global IT-related market size in 2016 was reported as $\$ 153$ billion [3]. IT equipment accounts for $40 \%$ of total data-center-operating costs [4].

In data centers with high-temperature IT equipment, enormous cooling systems are operated year-round to minimize the economic losses caused by malfunctions and errors of IT equipment [5]. Cooling-energy consumption accounts for approximately $31 \%$ of the total energy consumption in data centers [6]. Therefore, studies have been actively conducted on cooling systems that can improve heat-source efficiency by introducing air-side economizers to reduce the cooling energy consumed by data centers [7-12]. The air-side-economizer system can significantly reduce the cooling energy consumed by data centers. Representative air-side economizers applicable to data centers are divided into direct and indirect types, and the appropriate type must be selected at the design stage by considering the salt or dust contamination caused by regional characteristics [13].

A direct air-side economizer must effectively discharge the heated air that passes through a server rack to the outside, while the indirect air-side economizer must control the air flow through the 
installation of a separate wind path to prevent the recirculation of heated air. To date, many studies have been conducted on the improvement in cooling efficiency in the server-room unit, but analysis of cooling-energy consumption by considering the recirculation of exhaust air (EA) according to the shape of the data-center building has not been adequately researched. EA recirculation mixes part of the EA with outdoor air $(\mathrm{OA})$ and causes a rise in temperature, thereby lowering the cooling-load-reduction effect in air-side economizers. This means that it is necessary to consider the effects of recirculating air discharged to the outside when the changes in cooling-energy consumption with the application of an air-side economizer are analyzed. When cooling-energy consumption is calculated by considering EA recirculation, a more accurate analysis of this quantity will be possible. In addition, in server racks located in the server rooms of a data center, "hot" and "cold" aisles are alternately arranged to efficiently supply the cold air discharged from the computer-room air conditioning (CRAC) or computer-room air handler (CRAH) to the server racks [14]. In general, large data centers are operated using underfloor distribution systems.

This means that the cooling-energy consumption of the same heat-source system can be reduced by improving the cooling efficiency, thus increasing the temperature of the supply air (SA) delivered to the server room. This study calculated the cooling-energy consumption of an existing data center using dynamic-energy simulation and analyzed the cooling-energy saving effect considering the various condition of EA recirculation and SA-temperature when direct and indirect air-side economizers are applied to a data center in Korea.

\section{Cooling Load and Energy Consumption of a Conventional Data Center}

\subsection{Overview of Data Center}

Table 1 shows an overview of a data center. This major data center located in Seoul, Korea, has four underground floors and 12 ground floors; the IT server rooms are located from the second to the 10th floors. In addition, the data center has chillers installed in the underground machine room and uses a central chilled-water system, which cools the IT equipment by producing chilled water and supplying it to the server rooms on each floor. The floor height is $4800 \mathrm{~mm}$, and an underfloor distribution system is used for air distribution. In the air-distribution system, the air cooled by the CRAH cooling coil is supplied to the server racks through the cold aisles of the access floors and server rooms, and the heated air returns to CRAH through the hot aisles.

Table 1. Overview of data center.

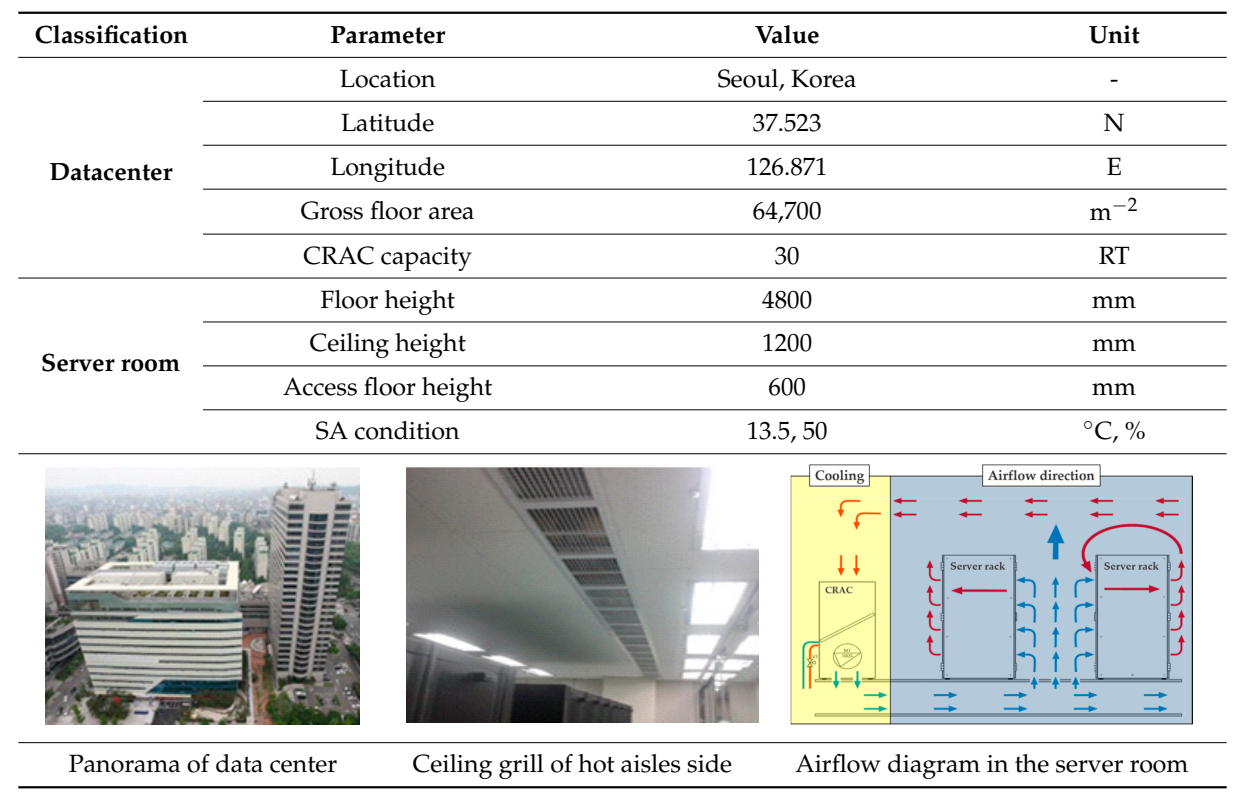




\subsection{Boundary Condition of Energy Simulation}

To calculate the cooling-energy consumption of the existing central chilled-water system in the data center, the cooling load of the server rooms must first be calculated. Table 2 shows the boundary conditions of the energy simulation. For the heat generated by IT servers, 6480 server racks were assumed to be installed, including $4 \mathrm{~kW}$-class server-rack 720 units per floor. The converted value of server heat was $2880 \mathrm{~kW}$ per floor. The cooling load generated by resident personnel and lighting was considered. For load-pattern changes according to server operations, values ranging from 0.7 to 1.0 were applied for each hour. TRNSYS (17.2, Thermal Energy System Specialists, Madison, WI, USA) was used to quantitatively analyze the annual cooling-energy consumption of the data center $(8760 \mathrm{~h})$. The meteorological data for Seoul provided by TRNSYS were used as the OA conditions [15].

Table 2. Boundary condition for calculating cooling load.

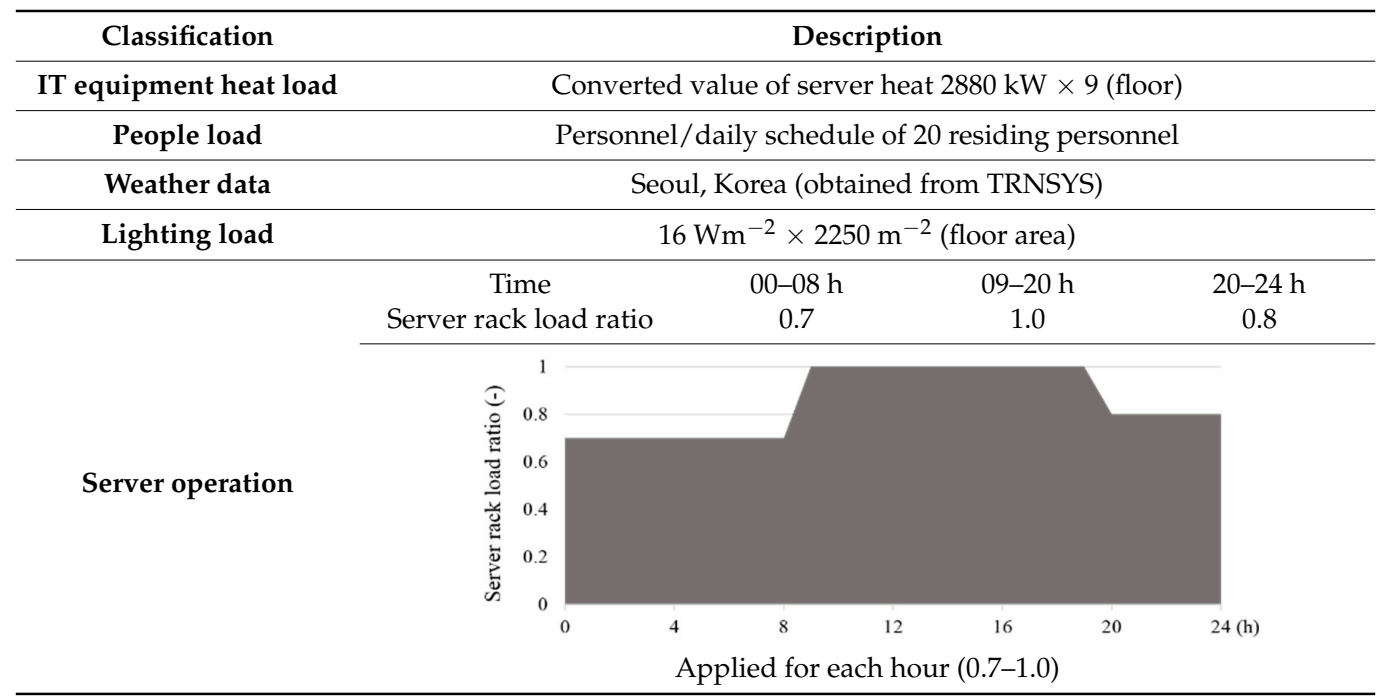

\subsection{Devices Used in Central Chilled-Water Systems}

\subsubsection{Water-Cooled-Chiller Component}

The components of the existing data-center cooling system and their specifications are listed in Table 3. The coefficient of performance (COP), which represents the performance index of a chiller, varies depending on the target inflow temperatures of the chilled and cooling water.

Table 3. Specifications of central chilled-water system.

\begin{tabular}{|c|c|c|c|c|}
\hline \multicolumn{2}{|c|}{ Component } & Specifications & Unit & Power Consumption \\
\hline \multicolumn{2}{|c|}{ Chiller } & $\dot{Q}_{R}=4567 \mathrm{~kW}, \mathrm{COP}=6$ & 8 & $765 \mathrm{~kW}$ \\
\hline \multicolumn{2}{|c|}{ Cooling tower } & Forced draft Cooling tower, $\dot{Q}_{R}=6345 \mathrm{~kW}$ & 8 & $120 \mathrm{~kW}$ \\
\hline \multicolumn{2}{|c|}{ Chilled water pump } & $\dot{m}_{c h w}=56,400 \mathrm{~kg} \cdot \mathrm{h}^{-1}, \mathrm{C}_{p, c h w}=4.19 \mathrm{~kJ} \cdot \mathrm{kg}^{-1} \cdot \mathrm{K}^{-1}$ & 8 & $110 \mathrm{~kW}$ \\
\hline \multicolumn{2}{|c|}{ Cooling water pump } & $\dot{m}_{c w}=93,600 \mathrm{~kg} \cdot \mathrm{h}^{-1}, \mathrm{C}_{p, c h w}=4.19 \mathrm{~kJ} \cdot \mathrm{kg}^{-1} \cdot \mathrm{K}^{-1}$ & 8 & $160 \mathrm{~kW}$ \\
\hline \multicolumn{2}{|c|}{ Outdoor air supply fan } & $26,450 \mathrm{CMH}$ & 648 & $11 \mathrm{~kW}$ \\
\hline \multirow[t]{2}{*}{ CRAH } & Cooling coil & $\begin{array}{l}\text { Number of rows }=5, \text { Number of tubes }=60 \\
\text { Tube outer diameter } 12 \mathrm{~mm} \text {; inner diameter } 11 \mathrm{~mm}\end{array}$ & 324 & $7.5 \mathrm{~kW}$ \\
\hline & Capacity & $22,800 \mathrm{CMH}$ & 324 & $7.5 \mathrm{~kW}$ \\
\hline
\end{tabular}


The COP value of the chillers used in this study was 6 based on the set chilled-water temperature of $7{ }^{\circ} \mathrm{C}$ and the cooling-water-inflow temperature of $30^{\circ} \mathrm{C}$ [15]. The chiller $\mathrm{COP}$ is calculated using Equation (1) and capacity under current conditions is calculated using Equation (2):

$$
\begin{gathered}
\mathrm{COP}=\mathrm{COP}_{\text {rated }} \times \mathrm{COP}_{\text {ratio }} \\
\text { Capacity }=\text { Capacity }_{\text {rated }} \times \text { Capacity }_{\text {ratio }}
\end{gathered}
$$

The chiller load is calculated using Equation (3).

$$
\dot{Q}_{\text {load }}=\dot{m}_{\text {chw }} \times C_{p, \text { chw }} \times\left(T_{c h w, \text { in }}-T_{\text {chw, set }}\right)
$$

In addition, the part load ratio (PLR), which is the ratio between the load capacity and design capacity of the chillers, was investigated and reflected in the simulation analysis. PLR is calculated by Equation (4), while the outlet temperature of the chilled-water stream is given as Equation (5).

$$
\begin{gathered}
P L R=\frac{\dot{Q}_{\text {load }}}{\text { Capacity }} \\
T_{\text {chw out }}=T_{\text {chw,in }}-\frac{\dot{Q}_{\text {met }}}{\dot{m}_{\text {chw }} \times C_{p, \text { chw }}}
\end{gathered}
$$

\subsubsection{Cooling-Tower Component}

The cooling tower is of a closed-circuit type. The cooling-water temperature difference (range) between the inlet and outlet of the cooling tower and the difference (approach) between the cooling-water-outlet and inlet-air wet-bulb temperatures was $5{ }^{\circ} \mathrm{C}$. The fan power of the cooling tower was set to an operational rate of at least $80 \%$ to prevent freezing in winter. In addition, the heat source used as the cooling and chilled water had a specific heat of $4.19 \mathrm{~kJ} \cdot \mathrm{kg}^{-1} \cdot \mathrm{K}^{-1}$. This cooling-tower model relied on the basic premise that the saturated-air temperature is the temperature at the air-water interface and that of the outlet fluid. With this assumption, the air enthalpy can be calculated from Equation (6) [16].

$$
h_{\text {sat }}\left(T_{f, \text { out }}\right)=h_{a}\left(T_{a, \text { in }}\right)+\frac{\dot{Q}_{f}}{\dot{m}_{a} \times\left(1-\exp \left[-\lambda_{\text {design }} \frac{\dot{m}_{a}}{\dot{m}_{a, \text { design }}}\right]\right)^{y-1}}
$$

Here, $y=0.6$ for most applications, and the designed outlet-fluid-temperature, air- and fluid-flow-rate, and inlet-air conditions are required by the cooling-tower model as parameters. We can use Equation (7) to calculate the design conditions $\left(h_{\text {air }}\left(T_{\text {air,out }}\right.\right.$ design $\left.)\right)$ as an unknown in order to solve for $\lambda_{\text {design }}$ [17].

$$
\lambda_{\text {design }}=\ln \left[\frac{h_{\text {sat }}\left(T_{f, \text { in,design }}\right)-h_{\text {air }}\left(T_{a, \text { in, design }}\right)}{h_{\text {sat }}\left(T_{f, \text { out }, \text { design }}\right)-h_{\text {air }}\left(T_{a, \text { out }, \text { design }}\right)}\right]
$$

The outlet-air enthalpy can be determined from the energy balance on the cooling tower and can be expressed as Equations (8) and (9).

$$
\begin{gathered}
Q_{\text {fluid,design }}=\dot{m}_{\text {fluid }} \times C_{p, f l u i d}\left(T_{\text {fluid,in,design }}-T_{\text {fluid,out,design }}\right) \\
h_{\text {air }}\left(T_{\text {air,out,design }}\right)=h_{\text {air }}\left(T_{\text {air,in,design }}+\frac{\dot{Q}_{\text {fluid,design }}}{\dot{m}_{\text {air }}}\right)
\end{gathered}
$$


The power of the cooling-tower fan is calculated using Equation (10).

$$
P_{\text {fan }}=\dot{P}_{\text {fan, rated }}\left\lfloor a_{0}+a_{1}\left(\gamma_{a}\right)+a_{2}\left(\gamma_{a}\right)^{2}+a_{3}\left(\gamma_{a}\right)^{3}+\ldots\right\rfloor
$$

\subsubsection{Cooling-Coil Component}

The central chilled-water system reduces the load on the chillers by bypassing the chilled-water flow into CRAH depending on the server-room heat. In this study, a simplified cooling coil was fitted as our model. The total heat-transfer rate across a chilled-water coil cooling a moist air stream is the difference in enthalpy across either flow stream, given as Equation (11).

$$
\dot{Q}_{t}=\dot{m}_{w} \times C_{p, w} \times\left(T_{w, o u t}-T_{w, \text { in }}\right)
$$

A third empirical relation for the total heat transfer is taken from the American Society of Heating, Refrigerating and Air Conditioning Engineers (ASHRAE) and given as Equations (12)-(16) [18].

$$
\begin{gathered}
\dot{Q}_{t}=N_{\text {row }} \times A_{f} \times B R C W \times W S F \times L M T D \\
\frac{1}{B R C W}=C_{1} \times \frac{C_{2}}{V_{a}} \times \frac{C_{3}}{V_{w}} \times \frac{C_{4}}{V_{w}^{2}} \times \frac{C_{5}}{V_{a}^{3}} \times \frac{C_{6}}{V_{w}^{2} V_{a}^{4}} \\
W S F=k_{1}+k_{2} \Delta T_{1}+k_{3} \Delta T_{1} \Delta T_{2}+k_{4} \Delta T_{1}^{2}+k_{5} \Delta T_{1} \Delta T_{2}^{2}+k_{6} \Delta T_{1}^{2} \Delta T_{2}+k_{7} \Delta T_{1} \Delta T_{2}^{3}+k_{8} \Delta T_{1}^{2} \Delta T_{2}^{3} \\
+k_{9} \Delta T_{1}^{3} \Delta T_{2}^{3} \\
\Delta T_{1}=T_{d p, i n}-T_{w, \text { in }} \\
\Delta T_{2}=T_{d b, \text { in }}-T_{w, \text { in }}
\end{gathered}
$$

where $B R C W$ is the heat transfer per unit face area per log-mean-temperature difference for an entering water temperature equal to the dew-point temperature of the entering air stream, WSF is a wetted surface factor, and LMTD is the log mean temperature difference between air and water-flow streams. In this study, BRCW and WSF were calculated using the empirical constant values of previous research [18]. However, operating conditions of cooling coil should be considered to use this equation because this model was developed to fit in the condition of specific range in terms of face air velocities, chilled water velocities, entering chilled water temperature, and dry bulb temperature of entering and leaving air.

The velocities of the air and water streams are calculated using Equations (17) and (18).

$$
\begin{gathered}
V_{a}=\frac{\dot{m}_{a}}{\rho_{a} \times A_{f}} \\
V_{w}=\frac{4 \dot{m}_{a}}{\rho_{w} \times \pi \times d_{i}^{2} \times N_{c o i l}}
\end{gathered}
$$

\subsubsection{Fan and Pump Components}

All fans and pumps operate at constant speed with on/off signal control. Fans have a variable air-flow rate, and pumps have a constant water-flow rate. The fan and pump efficiencies were set to $65 \%$. The power consumed by the fan and pump can be calculated as Equations (19) and (20), respectively [15].

$$
\begin{gathered}
P_{\text {fan }}=P_{\max }\left\lfloor c_{0}+c_{1} \beta+c_{2} \beta^{2}+c_{3} \beta^{3}+\ldots+c_{i} \beta^{i}\right\rfloor, \text { if } \dot{m}>0 \\
P_{\text {pump }}=P_{\text {rated }} \times \eta_{\text {motor }}
\end{gathered}
$$




\subsection{Cooling Load and Energy Consumption}

Figure 1 shows the cooling-load-calculation results. The cooling load generated in the server rooms of the data center ranged from 18,000 to $24,000 \mathrm{~kW}$, depending on the operation rate of the server, independent of the OA. This was because approximately $98 \%$ of the cooling load was generated by the server racks, meaning that enormous cooling energy was consumed even when the ambient temperature was low in winter. The percentage of power consumed by each component out of the total annual power consumption of the central chilled-water system is shown in Figure 2. The chillers accounted for $47 \%$ of the total power consumption. Therefore, it is expected that the power consumption of the chillers will decrease just by improving the cooling efficiency of the server rooms because of increasing the set-chilled water and SA temperature.

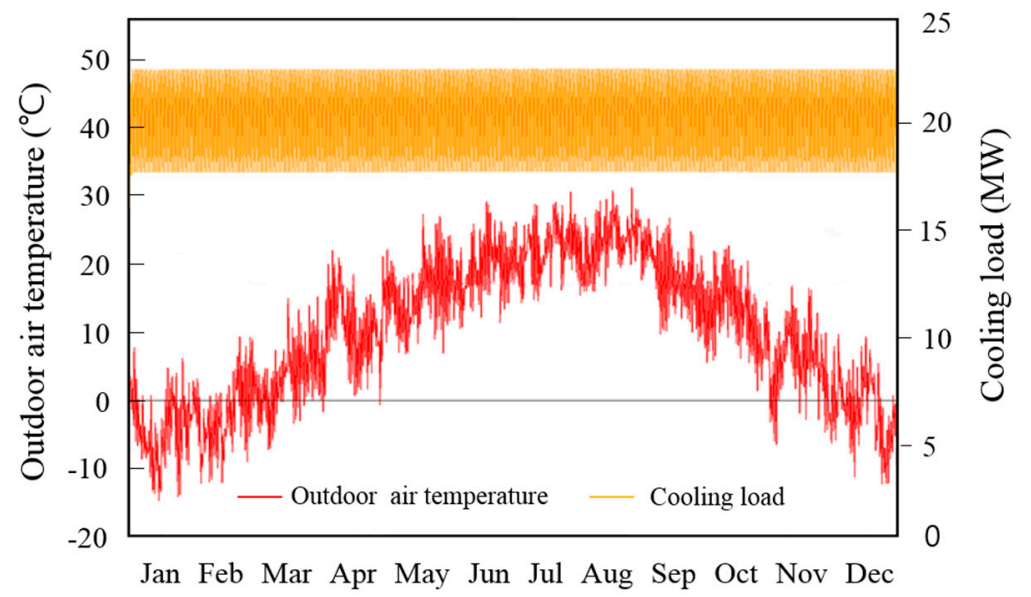

Figure 1. Monthly cooling load of server room.

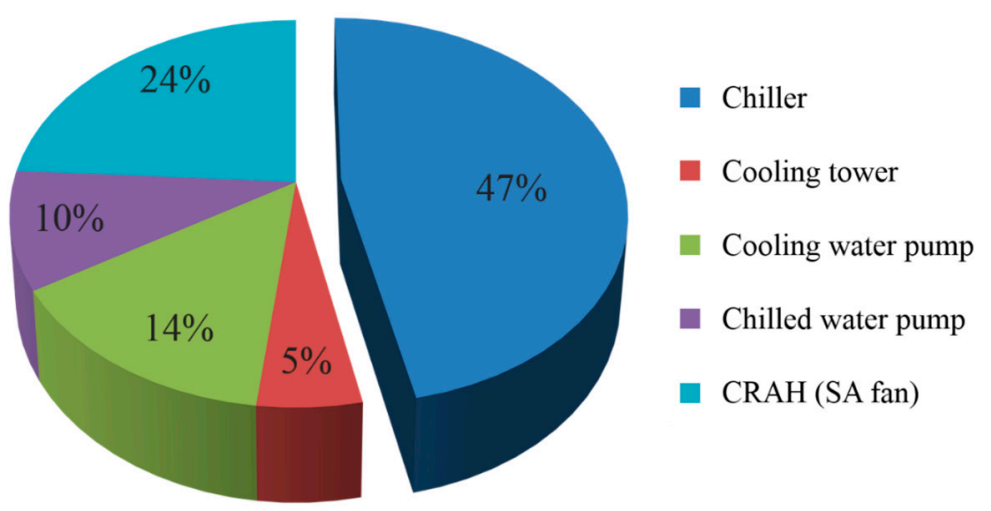

Figure 2. Percentage of power consumption of each component.

Figure 3 shows the monthly cooling-energy consumption of the central chilled-water system. The monthly power consumption of the components excluding the cooling tower and chillers was constant. This is because only the temperature of the chilled water returning to the chillers through the bypass control changes. The flow rate of the pump or the air volume of CRAH are held constant, regardless of the server-room heat and OA conditions. In addition, the energy consumed by the chillers increased with the ambient temperature. This was because COP decreased because the temperature of the cooling water flowing into the chillers increased as the outdoor-air wet-bulb temperature rose. This means that the energy consumed to produce the same amount of $5^{\circ} \mathrm{C}$ chilled water increased. The energy consumed by the cooling tower also increased slightly in the summer when the outdoor-air wet-bulb temperature was relatively high. 


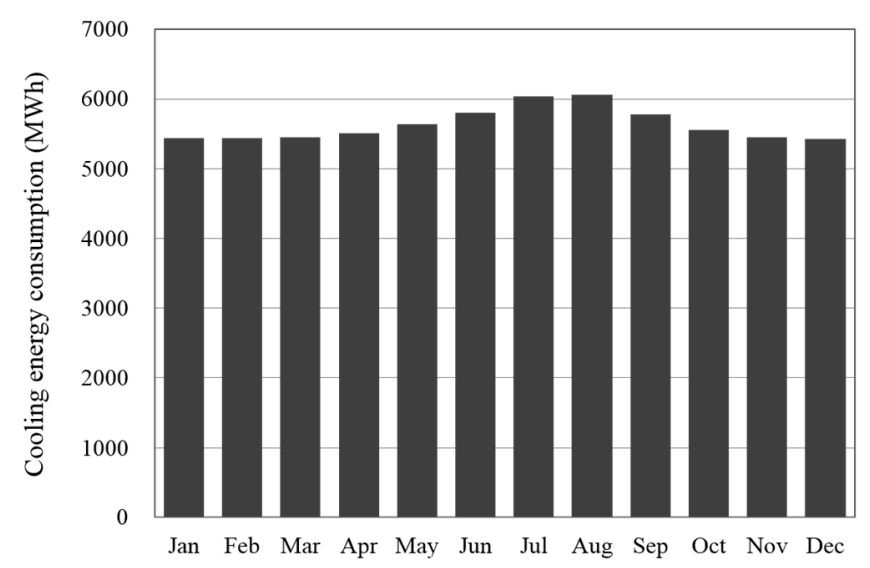

Figure 3. Monthly cooling energy consumption of central chilled-water system.

\section{Effect of Air-Side Economizers on Server Cooling in the Data Center}

\subsection{Case Study}

Table 4 shows the 13 cases examined in this study. In Case 1, the central chilled-water system was applied to the target data center; this is our reference case, and the SA temperature was $13.5^{\circ} \mathrm{C}$. The air-side economizers were divided into direct and indirect types. The parameters affecting the cooling-energy performance of each air-side economizer were the set SA temperature and the EA recirculation ratio. The recirculation ratio was set to $5 \%, 10 \%$, and $15 \%$ by taking advantage of the fact that the EA and OA grills of the data center are generally installed on the same side of the building.

Table 4. Condition of case.

\begin{tabular}{cccc}
\hline Case & Cooling System & SA Set Temperature & EA Recirculation Rate \\
\hline Case 1 & Central chilled cooling system & & - \\
Case 2 & & & $0 \%$ \\
Case 3 & & $13.5^{\circ} \mathrm{C}$ & $5 \%$ \\
Case 4 & With direct air-side economizer & & $10 \%$ \\
Case 5 & & & $15 \%$ \\
Case 6 & & $18{ }^{\circ} \mathrm{C}$ & $0 \%$ \\
Case 7 & & $22{ }^{\circ} \mathrm{C}$ & $0 \%$ \\
Case 8 & & & $5 \%$ \\
Case 9 & & $13.5^{\circ} \mathrm{C}$ & $10 \%$ \\
Case 10 & With indirect air-side economizer & & $15 \%$ \\
Case 11 & & $18{ }^{\circ} \mathrm{C}$ & $0 \%$ \\
Case 12 & & $22{ }^{\circ} \mathrm{C}$ & \\
Case 13 & & & \\
\hline
\end{tabular}

Equation (21) is used to calculate $T_{O A *}$, which was influenced by the recirculation of exhaust air.

$$
T_{O A *}=T_{O A} \times\left(1-r_{r e, E A}\right)+T_{E A} \times r_{r e, E A}
$$

Moreover, the SA temperatures were set, according to the improvement in cooling efficiency, as $18^{\circ} \mathrm{C}$ and $22^{\circ} \mathrm{C}$.

When EA recirculation was $15 \%$ under the climate conditions of Seoul, the direct-air-side-economizer-availability time decreased from $52 \%$ to $47 \%$ per year. On the other hand, when the SA temperature condition was changed to $22{ }^{\circ} \mathrm{C}$, it significantly increased from $52 \%$ to $78 \%$, even for an EA recirculation of $15 \%$. 
In addition, when a direct air-side economizer is used, equipment malfunctions arising from dust from OA must be prevented. Standard 52 of ASHRAE uses the minimum-efficiency-reporting-value (MERV) index and recommends MERV 11 through MERV 13 to improve the indoor air quality of the server rooms when OA is introduced. It recommends the use of no less than MERV 8 filters [19]. Therefore, in this study, it was assumed that MERV-8 and MERV 11 filters were installed in the OA fans, and that energy simulation was performed by considering an increase in fan power due to pressure loss.

\subsection{Direct Air-Side Economizer}

Figure 4 shows a schematic of a cooling system using a direct air-side economizer. When the outdoor temperature is low, OA is directly supplied or mixed with the return air (RA) and supplied to the server rooms to produce a cooling effect. When the outdoor temperature is high, the existing central chilled-water system is operated.

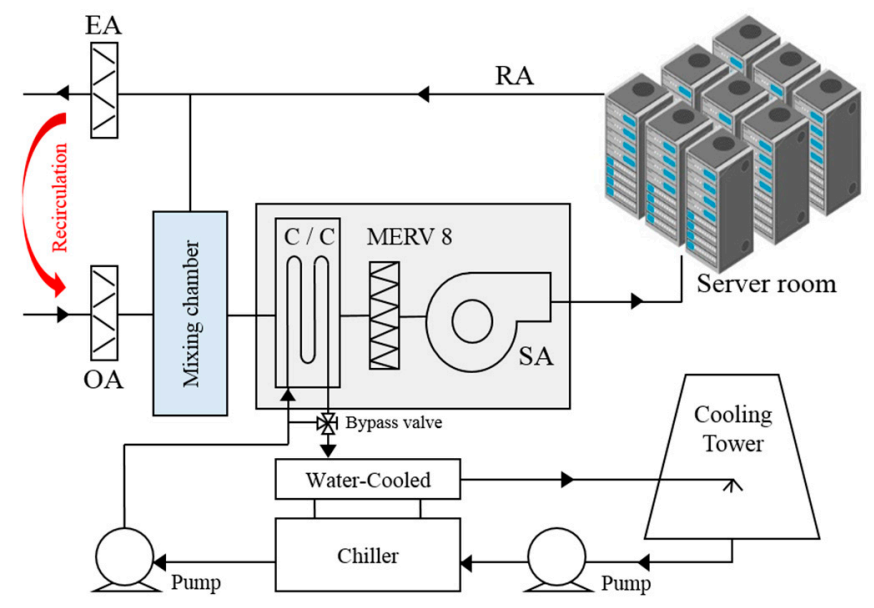

Figure 4. Direct air-side economizer schematic.

In this study, the OA availability time was calculated by assuming that OA was introduced at $25 \%$ mixing-ratio intervals, according to the temperature or enthalpy section under the climatic conditions of Seoul (Figure 5). As a result, the OA-availability times of the temperature and enthalpy control were 6269 and $5556 \mathrm{~h}$, respectively. In addition, $100 \%$ OA was set to be supplied to the server rooms under the condition that direct introduction of OA was possible.

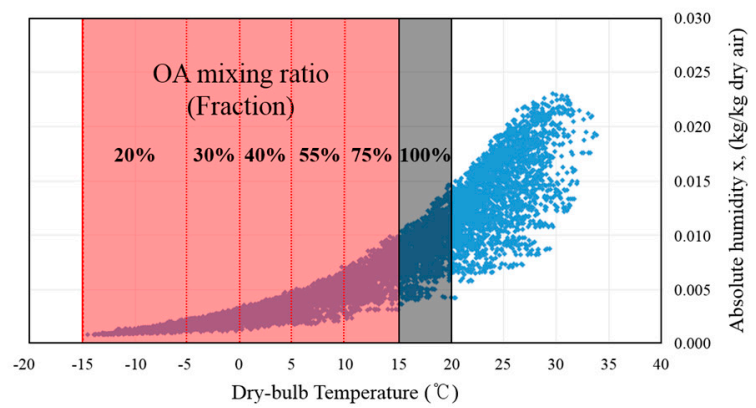

(A)

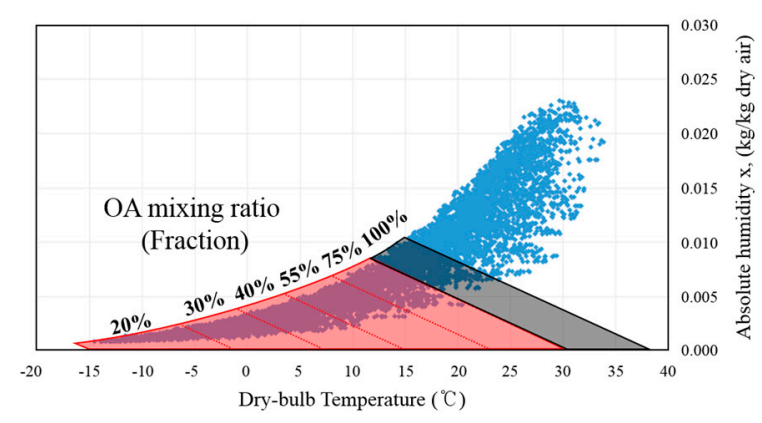

(B)

Figure 5. Annual outdoor air condition and outdoor air (OA) mixing ratio. (A) Temperature control; (B) Enthalpy control.

Figure 6 shows the SA condition delivered to the server rooms via CRAH when OA was introduced into each section. In the $75 \%$ mixing-ratio section, the SA condition became a 
high-temperature and low-humidity state by OA and RA mixing. Thus, when the direct air-side economizer is operated, the control is simple when the mixing ratio is calculated by section, but there are areas where the SA condition that passes through the mixing chamber fails to meet the ASHRAE standard [20].

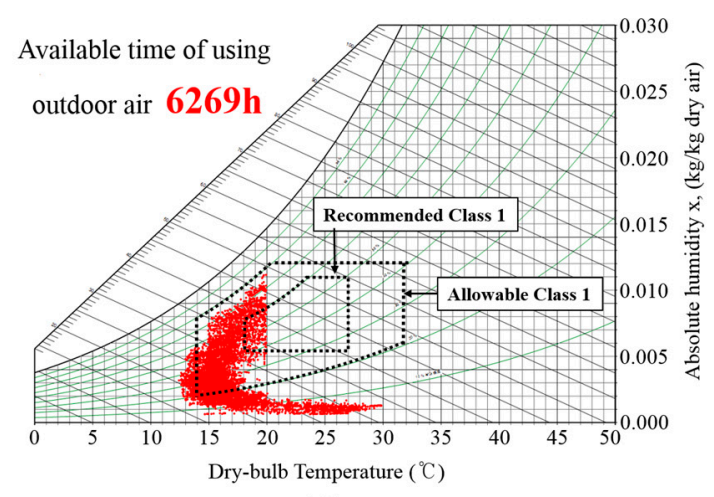

(A)

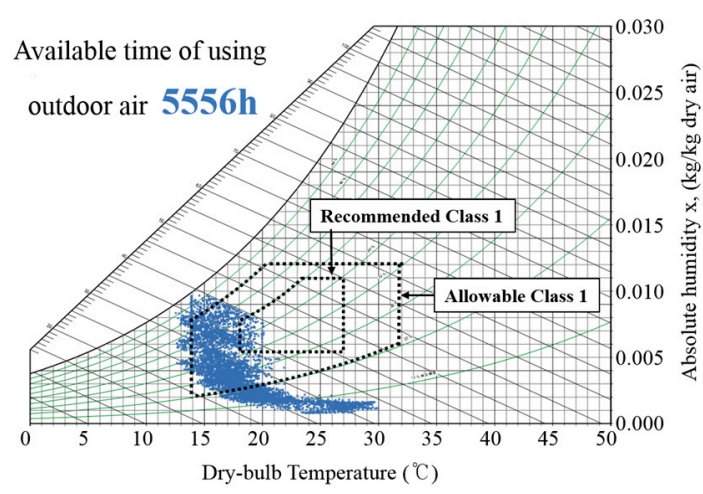

(B)

Figure 6. SA condition according to the OA mixing ratio. (A) Temperature control; (B) Enthalpy control.

\subsection{Indirect Air-Side Economizer}

The system schematic and operation algorithm of the indirect air-side economizer is shown in Figures 7 and 8, respectively. RA was first subjected to sensible heat exchange by adding an indirect heat exchanger to the existing central chilled-water system and was then supplied to the server rooms through cooling coils. The operation plan of the indirect air-side economizer was set to control three stages: one in which $\mathrm{RA}^{*}$ (the RA state when it passes through the primary indirect-heat exchanger) was at or below $13.5^{\circ} \mathrm{C}$, one in which $\mathrm{RA}^{*}$ was over $13.5^{\circ} \mathrm{C}$ but below $22.5^{\circ} \mathrm{C}$, and one in which $\mathrm{OA}$ was $22.5^{\circ} \mathrm{C}$ or higher. When $\mathrm{OA}$ is $22.5^{\circ} \mathrm{C}$ or higher, it is difficult to expect the cooling effect of the indirect air-side economizer; hence, the central chilled-water system, i.e., the existing cooling system, is operated. When $\mathrm{RA}^{*}$ is greater than $13.5^{\circ} \mathrm{C}$ but less than $22.5^{\circ} \mathrm{C}$, a parallel-operation mode is activated in which the indirect air-side economizer is responsible for the partial load and the central chilled-water system is used for the remaining cooling load. When RA* is less than $13.5^{\circ} \mathrm{C}$, the cooling load of the server rooms is handled only by the indirect air-side economizer. The heat exchanger component model described by Equations (22) and (23) is used [21].

$$
\begin{gathered}
T_{R A *}=T_{R A}+\varepsilon_{H X}\left(\frac{\dot{m}_{O A}}{\dot{m}_{R A}}\right) \times\left(T_{O A}-T_{R A}\right) \\
H X_{\text {flow ratio }}=\left(\dot{m}_{O A}+\dot{m}_{R A}\right) / 2 \dot{m}_{R A}
\end{gathered}
$$

In this study, the heat exchanger effectiveness was set at 70\% based on the Energy Performance Index of the Korean government [22]. Here, as the heat exchanger effectiveness increases, the temperature passing through the heat exchanger becomes closer to the outside air, and it is possible to reduce the coil load and save the cooling energy.

In addition, when the indirect air-side economizer and central chilled-water system were operated in parallel, the parallel operation was stopped and only the central chilled-water system was operated if the cooling energy consumed was higher than that consumed by a single operation of the existing central chilled-water system. On the other hand, in the case of the indirect air-side economizer, MERV-8 filters were applied because OA was not directly introduced into the server rooms, and the power consumed by the OA fan was calculated by considering the corresponding pressure loss. 


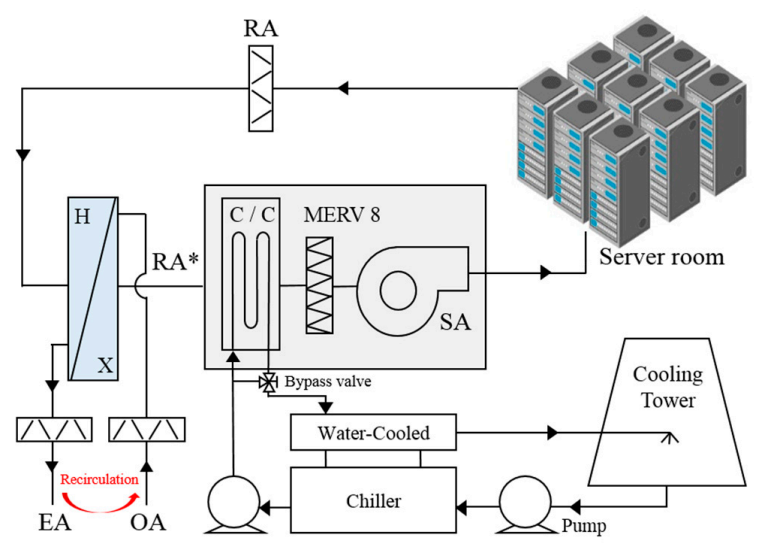

Figure 7. Indirect air-side economizer schematic.

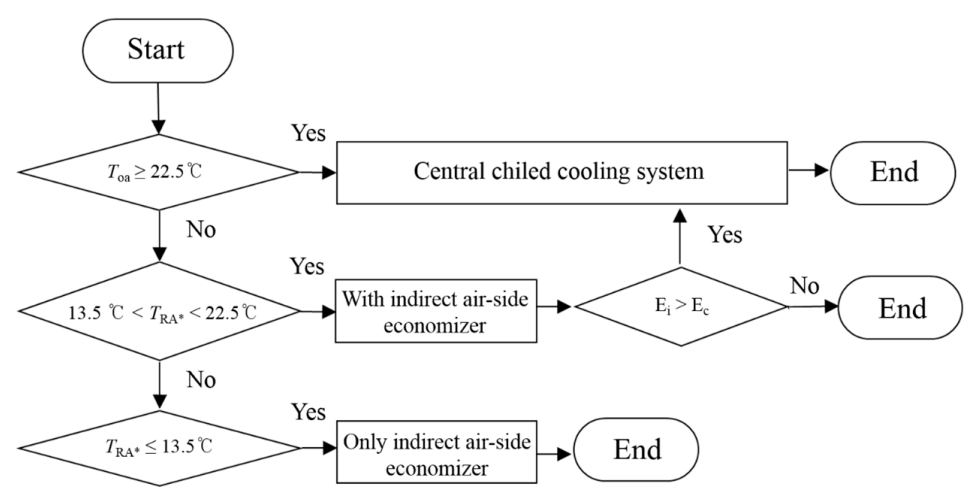

Figure 8. Indirect air-side economizer operation algorithm.

\subsection{Cooling Energy Consumed by Air-Side Economizers}

A case study on the change in cooling-energy consumption of the air-side economizer according to the EA-recirculation ratio and SA-temperature change was conducted. The results are shown in Table 5 and Figure 9. When the EA-recirculation ratio was $15 \%$, the annual cooling-energy consumption was approximately $6.1 \%$ higher than that in Case 2 (recirculation ratio $0 \%$ ). On the other hand, when the SA temperature was reduced to $22{ }^{\circ} \mathrm{C}$ when the direct air-side economizer was operated, the annual cooling-energy consumption was approximately $67 \%$ lower than that of the central chilled-water system. Therefore, it is expected that the improvement in cooling efficiency in the server rooms will significantly decrease the cooling-energy consumption of the data center.

In the indirect air-side economizer, at an outdoor temperature below $13.5^{\circ} \mathrm{C}$, an $\mathrm{HX}$ effectiveness of $70 \%$, and a recirculation ratio of $0 \%$, the amount of time spent processing the cooling load with only using OA was $3529 \mathrm{~h}$ per year. This increased to approximately $7000 \mathrm{~h}$ per year when parallel operation with the existing cooling system was included. In addition, the operation of the indirect air-side economizer was possible except for a certain period when the SA temperature was set to $22.5^{\circ} \mathrm{C}$. Thus, the annual cooling-energy consumption was reduced to approximately $45 \%$ compared to that of the existing central chilled-water system.

This result is similar to the annual cooling-energy saving ratio found by Ham et al. [21]. This previous study analyzed the cooling-energy consumption for various indirect air-side economizers.

As a result of the case study, it was confirmed that although the EA-recirculation ratio was adjusted to $15 \%$, the increasing of cooling-energy consumption was not higher than EA-recirculation ratio. 
Table 5. Results of case study.

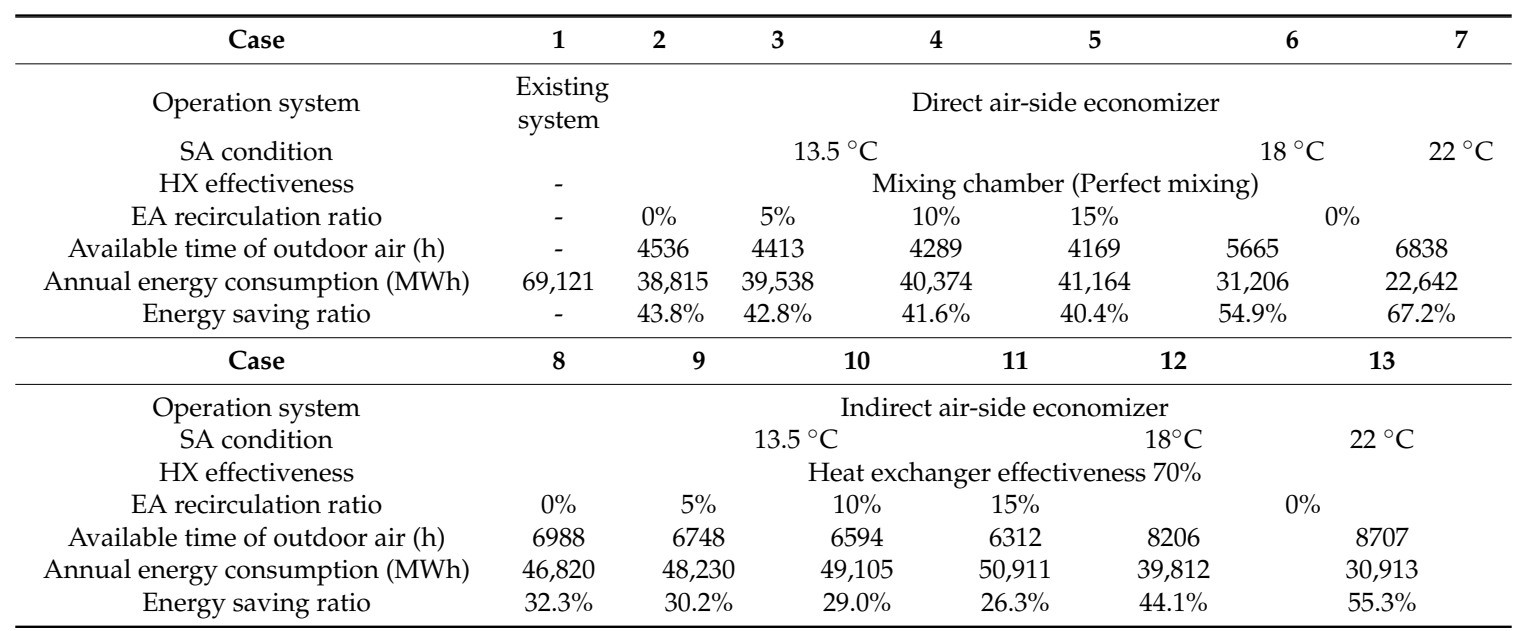

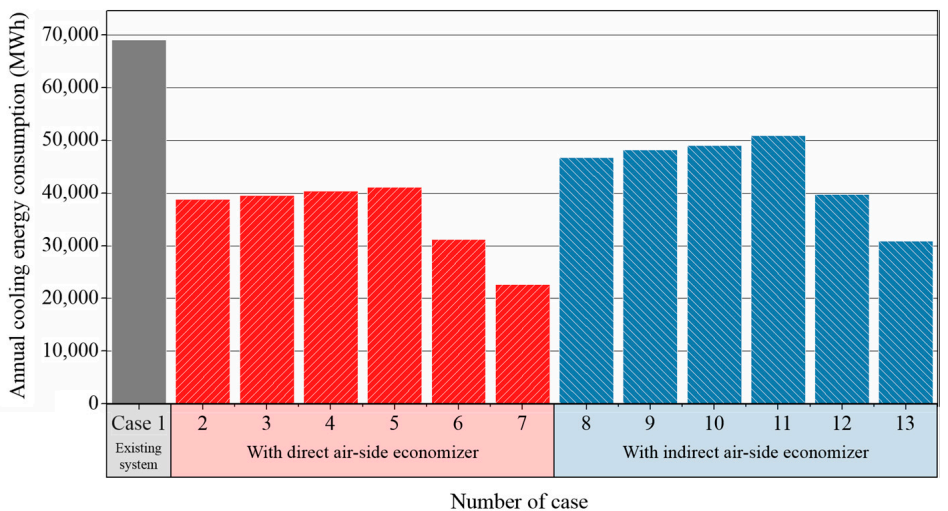

Figure 9. Annual cooling energy consumption of each case.

\section{Conclusions}

The present study used dynamic energy simulation to analyze the cooling-energy saving effect considering EA-recirculation and SA-temperature conditions when direct and indirect air-side economizers were applied to a data center in Korea. The conclusions of this study are as follows:

- When air-side economizers were used to reduce the cooling-energy consumption of the data center, the SA temperature exceeded the range recommended by ASHRAE when the mixing ratio was calculated by dividing the OA condition at regular intervals. Therefore, the mixing ratio of OA must be adjusted to meet the target SA condition according to the conditions of RA recirculation in the server rooms and of OA.

- In the direct air-side economizer, when the EA-recirculation ratio was $15 \%$, the annual cooling-energy consumption increased by approximately $6.1 \%$ compared to Case 2 . In the indirect air-side economizer, the cooling-energy consumption increased by approximately $9 \%$. This is because the use of OA was impossible owing to EA recirculation under climate conditions that would otherwise allow it. Therefore, EA grills must be installed such that the recirculation rate is lower than $5 \%$, or the envelope plan must be implemented at the design stage of the data center.

- When the SA-temperature condition was changed to $22{ }^{\circ} \mathrm{C}$, the annual cooling-energy consumption of the direct and indirect air-side economizers was reduced by approximately $67 \%$ and $55 \%$, respectively, compared to the case for the central chilled-water system. Therefore, it is expected that improving the cooling efficiency in server rooms will significantly reduce the cooling-energy consumption of data centers. 
- When the indirect air-side-economizer method is applied to data centers, server-rack malfunctions can be prevented because fine dust and moisture cannot be directly introduced into server rooms. In addition, it is expected that increment of SA set temperature and HX efficiency as well as EA-recirculation minimization will largely reduce the cooling-energy consumption of data centers, which accounts for enormous amounts of energy each year.

Acknowledgments: This work was supported by the National Research Foundation of Korea (NRF) grant funded by the Korean government (NRF-2015R1C1A1A01052784).

Author Contributions: Seonghyun Park provided main idea of the simulations, analyzed the simulation results and wrote the paper. Janghoo Seo reviewed the paper. All authors have read and approved the final manuscript.

Conflicts of Interest: The authors declare no conflict of interest.

\section{Nomenclature}

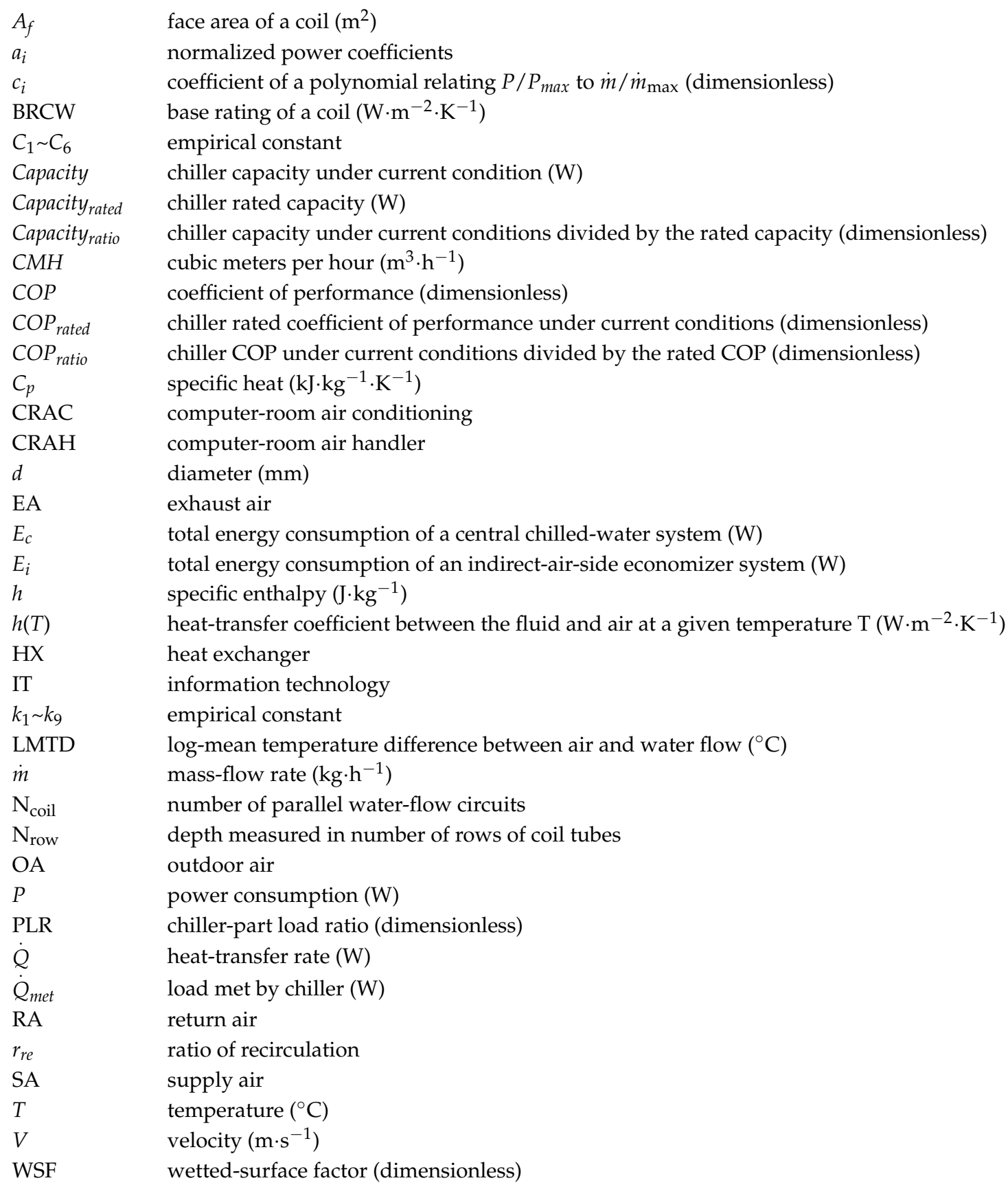




\section{Greek Symbols}

$\begin{array}{ll}\beta & \text { control function }(0 \leq \beta \leq 1) \\ \gamma & \text { ratio of flow rate to designed flow rate } \\ \varepsilon & \text { effectiveness } \\ \eta & \text { efficiency of pump motor } \\ \lambda & \text { thermal conductivity }\left(\mathrm{W} \cdot \mathrm{m}^{-1} \cdot \mathrm{K}^{-1}\right) \\ \rho & \text { density }\left(\mathrm{kg} \mathrm{m}^{-3}\right) \\ \text { Subscripts } & \\ a & \text { air } \\ c h w & \text { chilled water } \\ c w & \text { cooling water } \\ d b & \text { dry bulb temperature } \\ d e s i g n & \text { design condition } \\ d p & \text { dew point temperature } \\ f & \text { fluid } \\ H X & \text { heat exchanger } \\ i & \text { inside of tube } \\ \text { in } & \text { inlet } \\ \text { max } & \text { maximum } \\ \text { out } & \text { outlet } \\ R & \text { rated } \\ \text { sat } & \text { saturated-air condition } \\ \text { set } & \text { set point } \\ t & \text { total } \\ w & \text { water }\end{array}$

\section{References}

1. Fouladi, K.; Wemhoff, A.P.; Silva-Llanca, L.; Abbasi, K.; Ortega, A. Optimization of data center cooling efficiency using reduced order flow modeling within a flow network modeling approach. Appl. Therm. Eng. 2017, 124, 929-939. [CrossRef]

2. Van Heddeghem, W.; Lambert, S.; Lannoo, B.; Colle, D.; Pickavet, M.; Demeester, P. Trends in worldwide ICT electricity consumption from 2007 to 2012. Comput. Commun. 2014, 50, 64-76. [CrossRef]

3. Intel Intelligent Power Technology. Available online: http://www.canalys.com/newsroom/data-centerinfrastructure-market-will-be-worth-152-billion-2016 (accessed on 24 January 2018).

4. Kliazovich, D.; Bouvry, P.; Khan, S.U. DENS: Data center energy-efficient network-aware scheduling. Cluster Comput. 2013, 16, 65-75. [CrossRef]

5. Lee, E.K.; Kulkarni, I.; Pompili, D.; Parashar, M. Proactive thermal management in green datacenters. J. Supercomput. 2012, 60, 165-195. [CrossRef]

6. American Society of Heating, Refrigerating and Air-Conditioning Engineers. Best Practices for DataCom Facility Energy Efficiency; American Society of Heating, Refrigerating and Air-Conditioning Engineers: Altanta, GA, USA, 2009.

7. Lui, Y.Y. Waterside and airside economizers design considerations for data center facilities. ASHARE Trans. 2010, 116, 98-108.

8. Cho, J.; Lim, T.; Kim, B.S. Viability of datacenter cooling systems for energy efficiency in temperate or subtropical regions: Case study. Energy Build. 2012, 55, 189-197. [CrossRef]

9. Shrivastava, S.K.; Calder, A.R.; Ibrahim, M. Quantitative comparison of air containment systems. In Proceedings of the 2012 13th IEEE Intersociety Conference on Thermal and Thermomechanical Phenomena in Electronic Systems (ITherm), San Diego, CA, USA, 30 May-1 June 2012; pp. 68-77.

10. Udagawa, Y.; Waragai, S.; Yanagi, M.; Fukumitsu, W. Study on free cooling systems for data centers in Japan. In Proceedings of the 32nd International Telecommunications energy Conference (INTELEC), Orlando, FL, USA, 6-10 June 2010; pp. 1-5.

11. Tozer, R.; Flucker, S. Zero refrigeration for data centres in the USA. ASHRAE Trans. 2012, 118, $261-268$. 
12. Lee, K.-P.; Chen, H.-L. Analysis of energy saving potential of air-side free cooling for data centers in worldwide climate zones. Energy Build. 2013, 64, 103-112. [CrossRef]

13. American Society of Heating, Refrigerating and Air-Conditioning Engineers. Particulate and Gaseous Contamination in Datacom Environments; American Society of Heating, Refrigerating and Air-Conditioning Engineers: Atlanta, GA, USA, 2009.

14. American Society of Heating, Refrigerating and Air-Conditioning Engineers. Thermal Guidelines for Data Processing Environments; American Society of Heating, Refrigerating and Air-Conditioning Engineers: Atlanta, GA, USA, 2004.

15. TRNSYS. Available online: http://sel.me.wisc.edu/trnsys (accessed on 24 January 2018).

16. Zweifel, G.; Dorer, V.; Koschenz, M.; Weber, A. Building energy and system simulation programs: Model development, coupling and integration. Build. Simul-China 1995, 1995, 627-633.

17. Bergman, T.L. Introduction to Heat Transfer; John Wiley \& Sons: New York, NY, USA, 2011; ISBN 13-978-0470-50196-2.

18. Stoecker, W.F. Procedures for Simulating the Performance of Components and Systems for Energy Calculations; American Society of Heating, Refrigerating and Air-Conditioning Engineers: Atlanta, GA, USA, 1975.

19. Padilla, M.J. Method of Testing General Ventilation Air-Cleaning Devices for Removal Efficiency by Particle Size; American Society of Heating, Refrigerating and Air-Conditioning Engineers (ASHRAE): Atlanta, GA, USA, 1999; ISBN 9789992418635.

20. American Society of Heating, Refrigerating and Air-Conditioning Engineers. Thermal Guidelines for Data Processing Environments, 3rd ed.; American Society of Heating, Refrigerating and Air-Conditioning Engineers: Atlanta, GA, USA, 2012.

21. Ham, S.-W.; Kim, M.-H.; Choi, B.-N.; Jeong, J.-W. Energy saving potential of various air-side economizers in a modular data center. Appl. Energy 2015, 138, 258-275. [CrossRef]

22. Korea's Energy Performance Index. Available online: http://www.law.go.kr/admRulInfoP.do?admRulSeq= 2100000074054\&chrClsCd=010201 (accessed on 24 January 2018). (In Korean)

(C) 2018 by the authors. Licensee MDPI, Basel, Switzerland. This article is an open access article distributed under the terms and conditions of the Creative Commons Attribution (CC BY) license (http:/ / creativecommons.org/licenses/by/4.0/). 